\begin{tabular}{|l|c|c|c|r|}
\hline $\begin{array}{l}\text { Cuadernos de Investigación Geográfica } \\
\text { Geographical Research Letters }\end{array}$ & 2018 & N $^{\circ} 44(1)$ & pp. 171-185 & $\begin{array}{r}\text { ISSN 0211-6820 } \\
\text { eISSN 1697-9540 }\end{array}$ \\
\hline
\end{tabular}

DOI: http://doi.org/10.18172/cig.3379

\title{
THE GEOMORPHOLOGICAL ROLE OF SNOW SINCE THE LITTLE ICE AGE IN THE SIERRA DE ANCARES (NW SPAIN)
}

\author{
P. CARRERA-GÓMEZ, M. VALCÁRCEL* \\ Departamento de Xeografía, Universidade de Santiago de Compostela, \\ Praza da Universidade, 1, 15782-Santiago de Compostela (A Coruña), Spain.
}

\begin{abstract}
On the Pico Cuiña cirque, Sierra de Ancares (León, Spain), the seasonal snow cover undergoes both slow and rapid mass displacements. Push associated with moving snow is responsible for an intense geomorphological activity, which is characterised by the plucking and transport of fragments of the bedrock, the abrasion of rock surfaces and the deposition of the mobilized material. Pronival ramparts are the most characteristic accumulation geoform created by pushing snow. Its study enabled us to verify the functionality of the nival processes and to prove the relative antiquity of some of them. The use of lichenometric techniques, based on the prior construction of a growth curve for lichens of the Rhizocarpon subgenus, has made possible to date sectors of the pronival ramparts. Lichenometric dates show a series of events of geomorphic activity of the snow cover fitting chronologically within the so-called Little Ice Age. It can be deduced from the observation of the current geomorphic dynamics of the snow cover that, although Little Ice Age temperature decrease might be important, particularly in the summer, the role of the variations in snow precipitation must be also taken into consideration .
\end{abstract}

El papel geomorfológico de la nieve desde la Pequeña Edad de Hielo en la Sierra de Ancares (NW España)

RESUMEN. En el circo del Pico Cuiña, Sierra de Ancares (León, España), la cubierta nival estacional experimenta desplazamientos en masa que le confieren una notable capacidad de empuje basal. El empuje nival es, a su vez, responsable de una intensa actividad geomorfológica, caracterizada por el arranque y el transporte de fragmentos del substrato, la abrasión de superficies rocosas y la deposición del material movilizado. Las crestas o caballones de posición pronival (pronival ramparts) constituyen las geoformas de acumulación más características debidas al empuje nival. Su estudio, desde finales del pasado siglo, ha permitido comprobar la funcionalidad de los procesos que las originan, así como constatar la relativa antigüedad de alguna de estas geoformas. La utilización de técnicas liquenométicas, a partir de la elaboración previa de una curva de crecimiento de los líquenes del subgénero Rhizocarpon, ha permitido realizar 
una datación de distintos sectores de las crestas pronivales. Las dataciones han evidenciado una cronología de eventos de actividad geomorfológica del manto nivoso que se encuadra temporalmente dentro de la llamada Pequeña Edad de Hielo. Del estudio de la dinámica geomorfológica actual del manto nivoso y particularmente de su capacidad para crear y modificar crestas pronivales, puede deducirse que, en el caso de los eventos reconocidos como pertenecientes a la Pequeña Edad de Hielo, aunque pueda ser importante el descenso de las temperaturas, sobre todo las estivales, el papel de las variaciones en el aporte de nieve también debe ser considerado.

Key words: snow slide, snow push, pronival rampart, lichenometry, Little Ice Age, Sierra de Ancares, Northwest Spain.

Palabras clave: deslizamiento nival, empuje nival, pronival rampart, liquenometría, Pequeña Edad del Hielo, Sierra de Ancares, Noroeste de España.

Received: 23 July 2017

Accepted: 16 November 2017

*Corresponding author: Marcos Valcárcel, Departamento de Xeografía, Universidade de Santiago de Compostela, Praza da Universidade, 1, 15782 Santiago de Compostela (A Coruña), Spain. E-mail address: marcos.valcarcel@usc.es

\section{Introduction}

Snow plays a very important role in the current morphological evolution of the rock slopes of the Sierra de Ancares and, undoubtedly, in other sectors of the Cantabrian Mountains where its significance has gone unnoticed (Valcárcel et al., 2005; Carrera Gómez et al., 2006; Carrera Gómez et al., 2010; Santos González et al., 2010). In favourable locations where a deep snowpack is developed, snow cover can last almost half a year, attaining sufficiently large thicknesses to generate erosion and accumulation processes (Carrera Gómez and Valcárcel, 2010). Over much of this time period, mass displacements may occur, affecting the rock substrate. These movements can be attributed to both slow basal slide and occasional full-depth avalanches, which may take place following the acceleration of the sliding (Carrera Gómez et al., 2010; Carrera Gómez and Valcárcel, 2011a, 2011b). The combined pushing action of snow slide and full-depth avalanches cause intense erosion on the underlying rock surfaces, as well as accumulative processes at the lower sector of the area, which are directly responsible for the occurrence of debris accumulations similar to those termed by Shakesby et al. (1999) as pronival (protalus) ramparts (Valcárcel, 1998).

The aim of this study is to contextualize these pronival (protalus) ramparts as geoforms which result from the pushing action of a seasonal snow patch, as well as to locate them in time in the cold phases of the so-called Little Ice Age (LIA), estimating their absolute ages by means of lichenometric dating. 


\section{The study area}

The Sierra de Ancares is located on the western border of the Cantabrian Range, in the northwest of the Iberian Peninsula. Despite being geographically individual, structurally it clearly belongs to the Cantabrian Mountains. It acts as a divide between the basins of the Navia and Sil Rivers and is formed by a narrow main range running from Northeast to Southwest, where the highest peaks can be found (Miravalles, 1969 m; Cuiña, 1998 m). On its western side, the neighbouring hills descend gradually towards the Northwest and west until they reach the valley of the Navia River (Serra da Fiosa, 1403 m; Serra de Granda do Roxo, 1224 m; Serra do Pedreo, $900 \mathrm{~m}$ ). To the east it also gradually loses altitude towards the intermontane sedimentary basin of El Bierzo (Chana Grande, 1595 m; Pico de Las Plantigas, 1175 m; Pico Traviesas, $945 \mathrm{~m}$ ).

The study area is located in the highest sector of the Sierra de Ancares (León, Spain), in a broad glacial cirque, almost $1.5 \mathrm{~km}$ across, bordered by steep ridges that reach up to the Pico Cuiña (1998 m) (Fig. 1). It comprises a succession of three large thresholds, on which an abundance of rôches moutonnées and polished surfaces can be observed (Valcárcel, 1998; Valcárcel and Pérez Alberti, 2002). Pleistocene periglacial accumulations of quartzite macroclasts are common is this sector, particularly a rock glaciers, which developed at the feet of the most extensive slopes. Regarding Pleistocene rock glaciers, Valcárcel (1998) describes the occurrence of twenty of such geoforms in the Sierra de Ancares. Other authors cite the existence of two rock glaciers (Redondo Vega et al., 2010) although referred only to the study area of this work.

The bedrock comprises Ordovician quartzite and slate from the "Serie de Los Cabos", folded during the Hercynian orogeny (Pérez Estaún, 1978). Nevertheless the substrate of the highest levels of the Ancares Sierra is, for the most part, composed of quartzite. The study site shows a stepped topography, formed by an overlapping of nearly flat benches, defined by stratification planes, and sub-vertical faces, corresponding to joint planes (Fig. 1c and 1d).

Vegetation is scarce due to the dynamic conditions of the snow cover in this sector (Valcárcel, 1998) and is limited to annual herbaceous species and, particularly, to an uneven coverage of crustaceous lichens of the Rhizocarpon genus.

In the immediate surroundings of the study site, at an altitude of 1870 masl, a record of air temperature corresponding to the winter and spring of 2002-2003 was obtained. The average winter temperature (for the months from December to February) was $-1.3^{\circ} \mathrm{C}$, with an absolute minimum and maximum of $-12.2^{\circ} \mathrm{C}$ and $8.4^{\circ} \mathrm{C}$ respectively. During the spring (from March to May), the average temperature was $3.8^{\circ} \mathrm{C}$, with an absolute minimum and maximum of $-5.4^{\circ} \mathrm{C}$ and $19.9^{\circ} \mathrm{C}$, respectively (Carrera Gómez and Valcárcel, 2010).

The values of snow precipitation in the highest sectors of the Sierra de Ancares are unknown. Martínez Cortizas et al. (1999a) estimated an annual accumulated precipitation for the highest levels of the Sierra in excess of $2000 \mathrm{~mm}$, with $800 \mathrm{~mm}$ corresponding to the accumulated winter precipitation. However, these authors do not 
indicate the estimation of the percentage contributed by snow to the total annual volume of precipitation. On the other hand, Penas Merino et al. (1995) mention an average annual precipitation of $2022 \mathrm{~mm}$, recorded at the "Tejedo de Ancares" weather station, located at $990 \mathrm{~m}$ in the valley of the Ancares River.

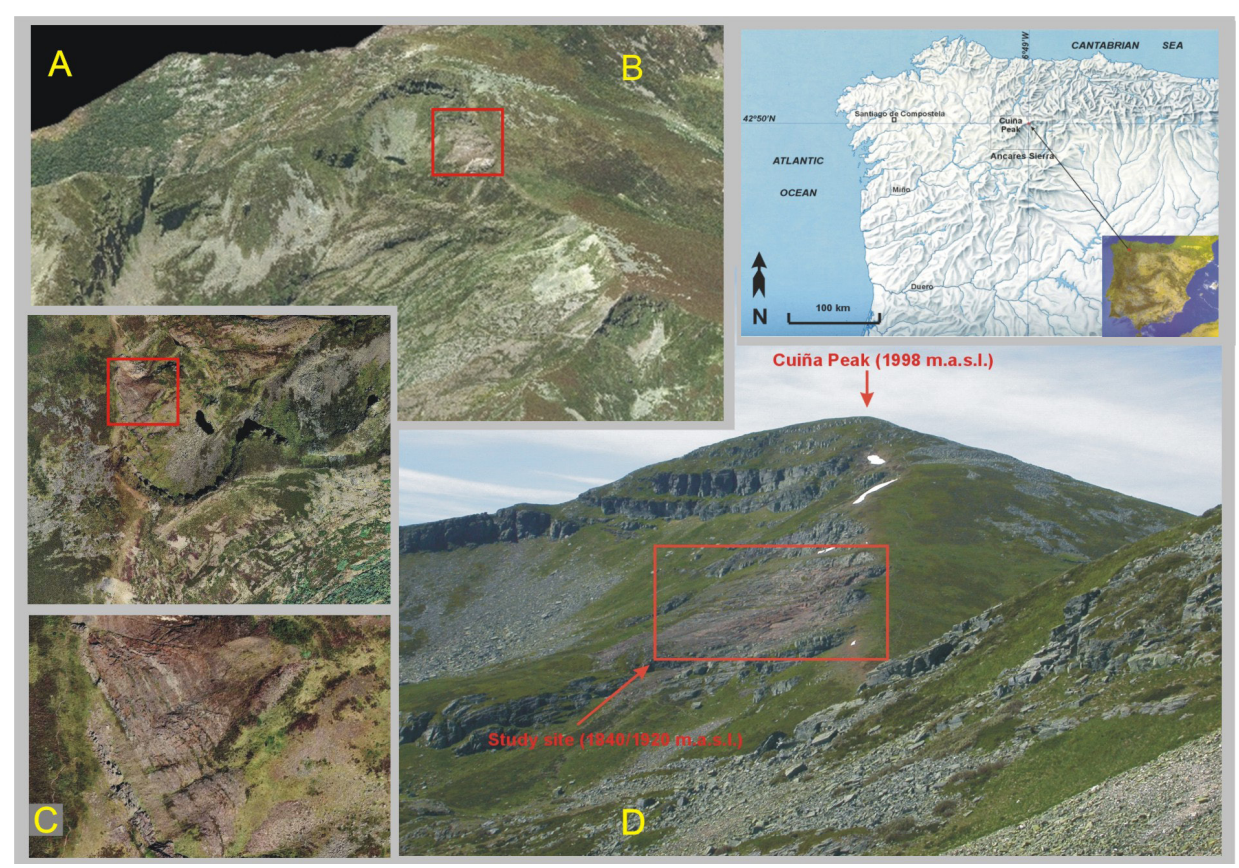

Figure 1. The location of the study area, different views of the site and a detail of the sector studied.

The seasonal snow cover in the area surrounding Pico Cuiña presents a series of particular features: a general duration of more than five months; significant thickness; a high density; a basal thermal regime close to $0^{\circ} \mathrm{C}$; the capacity for movement and the development of considerable subnival push (Carrera et al. 2010; Carrera Gómez and Valcárcel, 2011a, 2011b).

Over the course of the last decade, the duration of the snow cover has undergone noticeable inter-annual variations. In heavy snowy years, snow cover normally becomes established at the beginning of November, and the last remnants disappear in midJuly. On the other hand, in years with little precipitation, its formation is delayed until December and it disappears totally in May (Carrera Gómez et al., 2010, 2011b).

Maximum snow thickness frequently exceeds 4-5 $\mathrm{m}$ on the edge of the cirque, from which cornices are formed by wind-blown snow from the neighbouring western slope. The thickness varies considerably on the lower sectors of the slope due to the redistribution made by the wind and the irregular topography of the substrate (Carrera Gómez and Valcárcel, 2011b). 
During the ablation period, the snow cover presents extremely homogeneous stratigraphic features. Basal ice layers of up to $20 \mathrm{~cm}$ in thickness and densities exceeding $600 \mathrm{~kg} / \mathrm{m}^{3}$ are frequently formed, which are separated from the bedrock by a film of water. Above the basal ice, the cover is formed by coarse-grained, metamorphised snow with abundant of interstitial water and average densities of $550-570 \mathrm{~kg} / \mathrm{m}^{3}$ (Carrera Gómez and Valcárcel, 2011b).

The most notable feature of the snow cover is its mobility (Valcárcel, 1998; Carrera Gómez et al., 2010; Carrera Gómez and Valcárcel, 2010; 2011a; 2011b). The snow mass is usually affected by slow and rapid movements. The existence of slow basal sliding is indicated by the occurrence of tensile cracks, parallel to the contour lines in the snow cornices on the edge of the cirque. During slides the snow cover slips over the surface of the substrate, being displaced as a whole (Mathews and Mackay, 1963; 1975). According to McClung et al. (1994), this type of movement occurs on bare rock surfaces with gradients higher than $15^{\circ}$, but only when the temperature of the snow-substrate interphase is around $0^{\circ} \mathrm{C}$, thereby allowing the presence of liquid water, which acts as a lubricating film between the substrate and the snow cover. The average daily displacement can be measured in terms of millimetres (Clarke and McClung, 1999).

The instability caused by the basal slide tends to be more pronounced in spring, giving rise to full-depth avalanches extending up to $15 \mathrm{~m}$ (Carrera Gómez and Valcárcel, 2011b). Clarke and McClung (1999) point out that full-depth avalanches are intimately connected with snow slides, as they occur following periods of rapid sliding.

\section{Methods}

Nival accumulation forms were identified on the study site and a detailed geomorphological cartography was subsequently elaborated from field observations. Initially, a topographical survey was carried out using a Leica TC307 total station and GPS measurements, which enabled us to precisely locate the accumulation forms. Later, the possibility of using LIDAR (Light Imaging Detection and Ranging) data has put much more detailed topographical data at our disposal. A Digital Terrain Model (DTM) was created, based on LIDAR data from the Spanish National Geographic Institute. Orthophotos, obtained in 2014, were overlaid onto the DTM. The resulting DTM-LIDAR model, completed with coordinates obtained on the ground attained a resolution of $1 \mathrm{~m}$. All the data were processed with ArcGis 10.1 and SAGA GIS software and the cartographic information was edited using the cover generated in the Corel Draw 12 editing program.

Alichenometric study comprising the identification of the species and the elaboration of a lichen growth curve was carried out. The growth curve enabled us to obtain the age of the surveyed nival ridges.

The lichenometric techniques employed to date the forms of periglacial and nival origins have not, to date, been widely applied in the Iberian Peninsula (Chueca, 1991; Chueca Cia and Julián Andrés, 1992, 1995; Serrano, 1991; Martínez Piñeiro et al., 1998; Mateo García, 1998; Mateo García and Gómez Ortiz, 1998; Pérez-López et al., 2012). The technique is based on the assumption that the growth of lichen is continuous, albeit 
affected by environmental factors, from the moment when the rock surface is exposed (Beschel, 1950). Large specimens of a certain species are, therefore, the oldest and their age will coincide with the date of exposure of the colonized bedrock, if no external event has occurred which may have modified the rock surface. The dating may be relative, based on the estimation of the rate of re-coverage, or absolute, via the drawing of a local growth curve (André, 1993). We have chosen the second option, given the availability of a growth curve (Martínez Piñeiro et al., 1998).

The identification of the specimens of the Rhizocarpon subgenus was made following the common methodology in lichenology: a macroscopic study (of the thallus), a microscopic study (of the apothecium and the thalli structure) and chemical techniques (both macro and microscopic) with the necessary reactives ("K", "P", "I" and "C"). The bibliography used was also habitual in the determination of lichens (Clauzade and Roux, 1985, 1987, 1989; Purvis et al., 1992), along with the specific bibliography for the identification of the Rhizocarpon genus (Feuerer, 1978; Poelt, 1988; Runemark, 1956; Thomson, 1967).

More than two hundred samples of yellow Rhizocarpon have been identified in the Sierra de Ancares, with $78 \%$ of the species belonging to the Geographicum Cern. section and $11 \%$ to the Alpicola (Runem) Thoms section. The remaining $11 \%$ belongs to the Superficiele (Runem) Thoms section (Martínez Piñeiro et al., 1998). These data are similar to those published for other areas (Gordon and Sharp, 1983; Werner, 1990, Chueca Cia and Julián Andrés, 1992).

Once the representative nature of the different species of Rhizocarpon was determined, the next step was to identify sites in which their growth could be dated accurately. Ten sites, comprising precisely dated constructions, were studied (Table 1). In order to avoid the possibility of a coalescence of two lichens being interpreted as a single specimen, only the most developed isolated and circular specimens were measured. Disperse and malformed thalli were rejected. The largest specimens found did not exceed $46 \mathrm{~mm}$, smaller than the $70 \mathrm{~mm}$ considered by Innes (1982) as the maximum diameter acceptable in order to establish the growth of the Rhizocarpon subgenus.

Table 1. Characterization of the control stations used in this study.

\begin{tabular}{|l|c|c|c|c|c|}
\hline \multicolumn{1}{|c|}{ Site } & Year & Age* $^{*}$ & $\begin{array}{c}\text { Larger axis } \\
(\mathbf{m m})\end{array}$ & Lithology & $\begin{array}{c}\text { Altitude } \\
(\mathbf{m})\end{array}$ \\
\hline Capilla O Fabal & 1726 & 272 & 46 & quartzite & 540 \\
\hline Ferrería & 1788 & 210 & 42 & quartzite & 1000 \\
\hline Fábrica de luz & 1930 & 68 & 29 & slate & 860 \\
\hline Cabaña Forestal & 1957 & 41 & 28 & slate & 1140 \\
\hline Caseta Forestal UK n ${ }^{\circ} 883$ & 1957 & 41 & 23 & quartzite & 1530 \\
\hline Carretera Piornedo & 1964 & 34 & 19 & quartzite & 920 \\
\hline Capilla Ferreiravedes & 1972 & 26 & 16 & slate & 910 \\
\hline Capilla Airoa & 1982 & 16 & 13 & slate & 800 \\
\hline Capilla San Bernabé & 1983 & 15 & 19 & slate & 1060 \\
\hline Amiña de Piornedo & 1985 & 13 & 9 & granite & 1000 \\
\hline
\end{tabular}

* Age referred to 1998, date of sampling. 
With these data we were able to construct a growth curve for the studied sites. The function that relates age with diameter is in accordance with a logarithmic function expressed as follows:

$$
\mathrm{Dm}=11.4 \text { Ln Ed-19 }
$$

where Dm is the diameter of the lichen, $\mathrm{Ln}$ is the base of the natural logarithm and Ed is the age of the site in which the sample was measured. The correlation coefficient is 0.98 and the error of the estimate is $\pm 1.8 \mathrm{~mm}$ (Fig. 2a). This curve is extremely similar to those presented by other authors using the same type of lichen (Schroeder-Land, 1983; Serrano, 1991; Chueca, 1991; Chueca Cia and Julián Andrés, 1992; Mateo García and Gómez Ortiz, 1998). Given the good fit, it was considered appropriate to use the radial growth of the lichen as an estimation of the age. Thus, a new regression function was obtained in which the dependent variable is the age and the independent variable is the size of the lichen. The resulting exponential function fits in well with the behaviour expected from the lichen in terms of its growth as it acquires an asymptotic behaviour (the bigger the lichen, the smaller its radial growth). Therefore, the function is expressed as follows:

$$
\mathrm{Ed}=5.5 \mathrm{e}^{0.086 \mathrm{Dm}}
$$

The correlation coefficient is 0.98 and the error of the estimate is \pm 6 years. These results indicate that the fit is extremely significant and that it is possible to employ this function in order to predict the age based on the maximum radial growth observed on site (Fig. 2b).

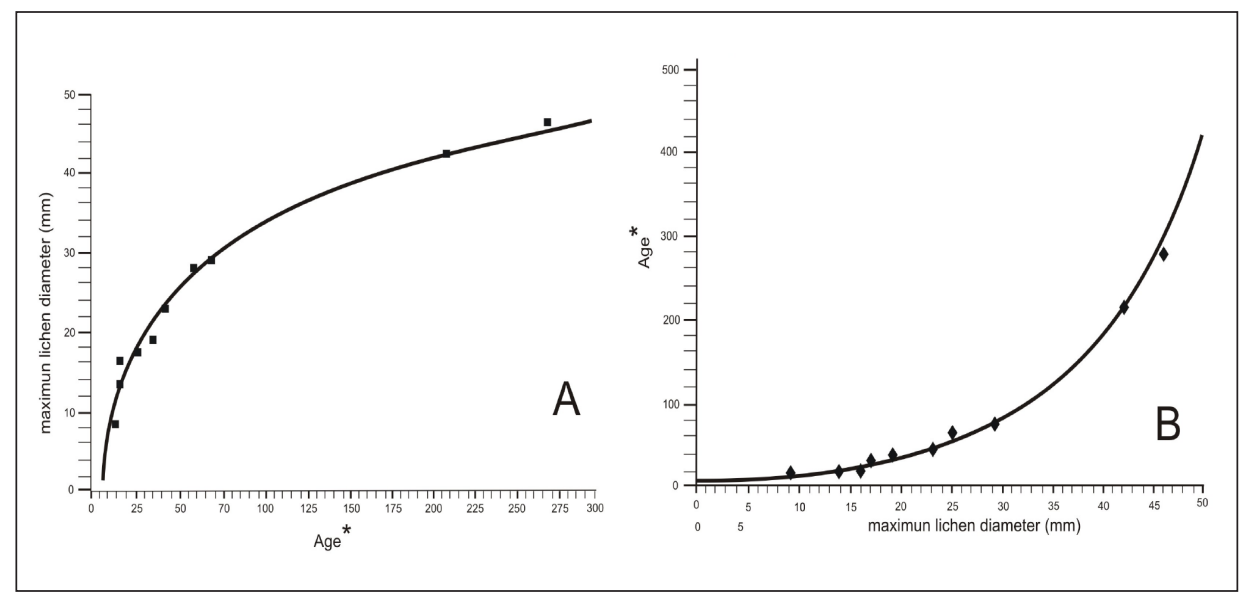

Figure 2. A: The local growth curve of the lichens of the Rhizocarpon subgenus. B: The function of age prediction based on the size of the lichens measured in the field. 


\section{Results}

Three pronival ramparts occur on the eastern sector of the study site. They are located at the foot of a section of hillslope formed by densely fissured slate, providing an abundant clast supply. Two of them, sickle-shaped in plan, show a frontal position, perpendicular to the direction of snow displacement (Fig. 3a and 3b). The third ridge lies in a frontal-lateral position, with its upper section lying sub-parallel to the direction of the movement of the snow. Its lower section is arcuate and lies perpendicular to the direction of the flow of the snow. The maximum height and width of the accumulations are 1.7 and $3 \mathrm{~m}$ respectively, with the frontal-lateral ridges exceeding $10 \mathrm{~m}$ in length. The cross-section profiles are asymmetrical. The proximal (internal) slopes have a gentler gradient than the distal (external) slopes.

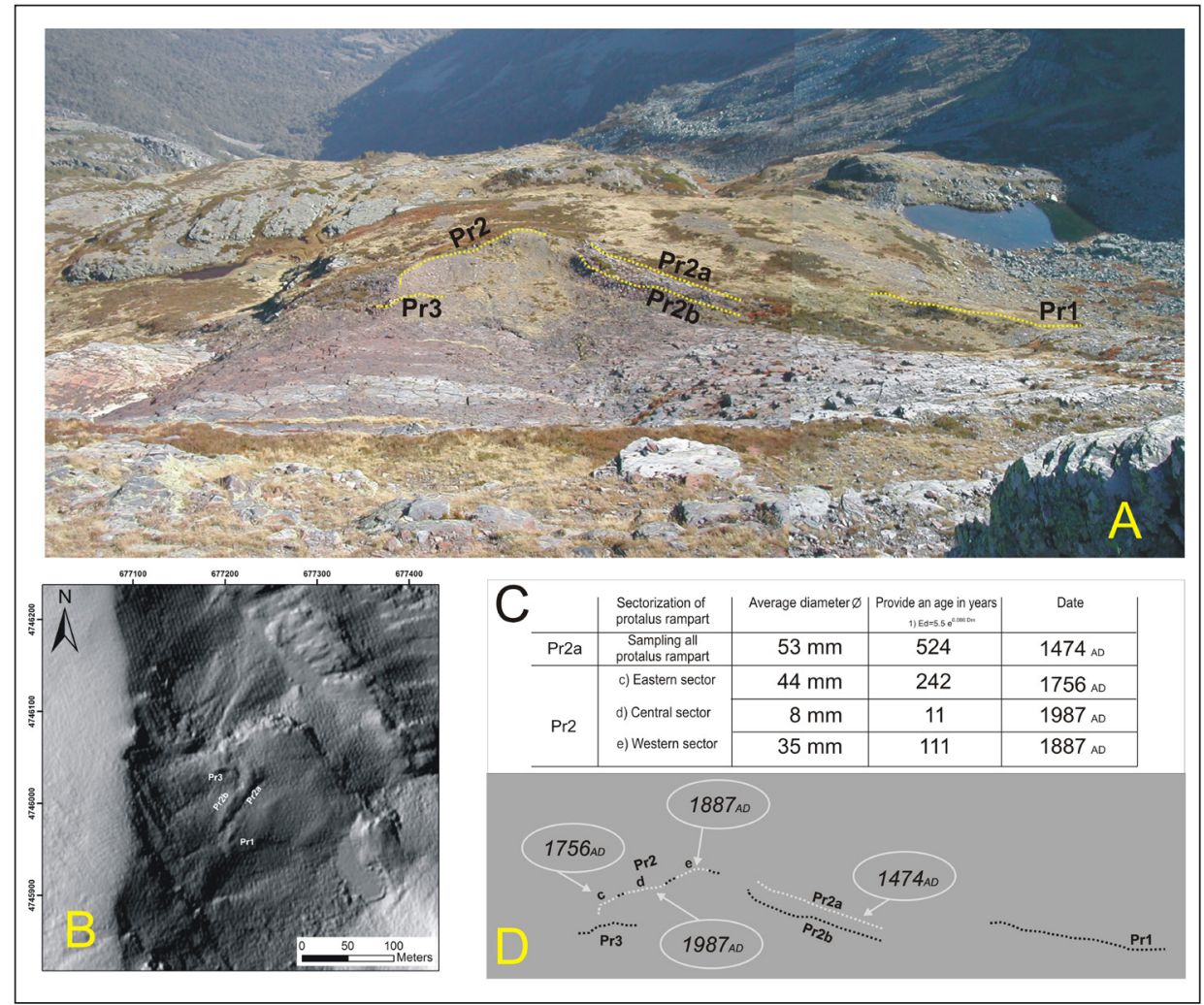

Figure 3. A: The view from the top of the Protalus ramparts. B: DTM of $1 \mathrm{~m}$ resolution from LIDAR data. C: Dates obtained from lichenometric data, expressed in calendar dates. D: Location on the protalus rampart of the sectors sampled and the dates obtained.

The frontal pronival ramparts are formed by a matrix-supported diamicton with abundant fine-grained material, whereas the lateral ridge of the frontal-lateral rampart is composed with open work blocks. The clasts in the ramparts usually show worn edges and 
striated faces and the proximal slopes of the frontal ramparts present blocks embedded in the matrix of fine-grained material. Such evidence clearly point to a subnival origin of the ramparts.

The basal pushing of the snow cover has partially reworked the crest of the frontallateral rampart in its lower part, creating a flattened surface with clasts embedded in the matrix of fine-grained material. The proximal slopes are bare of vegetation or slightly colonised by herbaceous species. The distal slopes, on the other hand, have been colonised by vegetation due to the fact that they are protected from the pushing action of the snow cover.

In order to conduct the lichenometric analysis the pronival ramparts were divided into sectors, according to the size of the thalli. The data obtained can be seen in Fig. 3c. The application of function 2 to thallus size data allowed us to establish absolute ages for the different sectors studied.

It has been not possible to date PR1 using this method, but we presume this rampart to be thousands of years old. As a rough guide, extrapolating the age of the lichens growing on the vertical faces of bedrock steps, protected from subnival abrasion, which reach a maximum axis of $80 \mathrm{~mm}$, the minimum age would appear to be 5349 years. Evidently, the degree of uncertainty produced by an estimation based on the available curve does not allow us to take this as a true value, although it can be considered to be an indicator of the age of both the lichens and, indirectly, of the external ridge.

The pronival rampart sector PR2a has been dated with an absolute age of 524 years \pm 6 (as of 1998), which corresponds to the year 1477. It has been well preserved due to its lateral position and the large size of the clasts from which it is formed (Fig. 3d).

Rampart sector PR2b corresponds to a second cold phase, dated to the year 1756. Sector PR2c represents a third event, corresponding to the year 1887 (Fig. 3a and 3c), which partially overlaps the former. Finally, dating of rampart sector PR2d showed a much more recent age, calculated at the year 1987.

\section{Discussion}

The obtained dates are coherent and close to the times of maximum cooling. The pronival rampart sector PR2a fits extremely well within the period known as the Little Ice Age. This ridge corresponds to the year 1477, coinciding with the first cold waves of the LIA (Grove, 1988).

However, it must be taken into account that what is being dated represents the activity of the snow cover. This activity does not depend only on the lowest temperatures but on their seasonal distribution, which must be a key factor, as well as on snow precipitation. Bearing this in mind, the dating of rampart sector PR2d (calculated at the year 1987) is extremely revealing. Although Schroeder-Land (1983) recommends only the use of specimens with radiuses greater than $25 \mathrm{~mm}$ for dating, and those used were much smaller than this, it is true that 1985, 1986 and 1987 were heavy snowy years in Northwest Iberia. This precipitation was mostly registered at early spring (March-April). 
However, there is no trace of the winters of the end of the 1960s and the beginning of the 1970s, which were particularly cold all over Europe. This may be due to the fact that the evidence thereof has been erased by more recent events. Finally, the winter of 20002001 was particularly rainy and snowy in the Northwest of the Iberian Peninsula, a fact which led to a deep remodelling of the nival ridges, erasing a large part of its historical evidence.

The study of the nival accumulation forms allows reconstructing a depositional sequence up to the present day, which is defined by the occurrence of four distinct morphogenetic phases (Figures $3 \mathrm{a}$ and $3 \mathrm{~b}$ ):

Phase 1. During this morphogenetic phase a small cirque glacier developed an overdeepening depression and a moraine enclosure.

Phase 2. Characterized by the presence of a snow patch, which was possibly perennial, given the area it occupied. It caused the deposition of a matrix-supported fines-rich pronival rampart (PR1), now colonised by vegetation.

Phase 3. In this phase the snow patch must have split in two, depositing a second set of pronival ramparts (PR2a, PR2b, PR2c and PR2d), consisting of a well-defined external crest with another internal one attached. These ramparts show an open fabric with clast-supported structure and are mainly formed by blocks.

Phase 4. During this phase the snow patch became seasonal and created a small, sub-current pronival crest (PR2b, PR3a).

The relative dating of the ramparts can be correlated with the data available for the north-west of the Iberian Peninsula. Therefore, we can relate the presence of a small, active cirque glacier (Phase 1) with the latter phases of the global Late Glacial period. The high rate of lichen coverage of the morainic clasts and the occurrence of coalescent and disintegrated thalli are indicators of their age.

Following the disappearance of the cirque glacier a snow patch became established (Phase 2), which was presumably permanent. It is not possible to precisely locate it in time. However, proxy data studies on peat bogs in the north-west of the Iberian Peninsula suggest that the so-called Cold Epoch of the Iron Age was the coldest point during the Holocene period (Martínez Cortizas et al., 1999a, 1999b) and was similar in intensity to the so-called LIA, although it lasted longer, making it logical to situate the most external ramparts created by the snow patch in this period.

Later in time, presumably after a long hiatus, the snow patch became seasonal (Phases 3 and 4). Data referring to physiographic descriptions corroborate the occurrence of late-lying snow patches in this area in recent times (Iglesias and Iglesias, 1927). The presence of a seasonal snow cover is indicated by the existence, in locations protected from the abrasive effect of the snow such as the vertical sections of bedrock structural steps, of a moderate lichen cover with thalli ranging between 20 and $80 \mathrm{~mm}$. These thalli presumably represent growths of hundreds of years, perhaps even more than a millennium, if the elaborated growth curve is extrapolated. That is to say, over a long period of time the snow cover was seasonal, although the ridges with evidence of its 
activity do not extend beyond six hundred years of age. However, this does not mean that there was no prior, less intense, activity that may have been erased by events related to the LIA, which was more intense than the previous phases.

Thus, a second set of pronival ramparts was established, PR2, which according to its lichen cover can be subdivided into sections: PR2a and PR2b in the eastern sector of the rampart, and PR2c, PR2d and PR2e in its western sector. The section PR2a, a rampart crest, shows a certain degree of lichen colonisation. However, the attached internal rampart crest (PR3 from Phase 4) is completely lacking in lichen. In the Sierra de Ancares the amount of time necessary for the lichens to become established is approximately five years (Martínez Piñeiro et al., 1998). Therefore, it should be supposed that this geoform is, at the most, of that age.

Later observations have enabled us to identify the processes responsible for these accumulations. In any case, there is evidence of the presence of a sub-actual seasonal snow patch, whose geomorphic activity comprises the basal dragging of clasts over the bedrock, causing striations and abrasion marks (Valcárcel, 1998; Carrera Gómez et al., 2010). Both the polished bedrock and the overlying abraded clasts are completely free of lichens. This indicates that the abrasive action is sufficiently intense to impede the growth of lichens. Only the vertical faces of the structural steps of the bedrock, which are protected from nival abrasion, show a dense colonisation of lichens with an abundance of Rhizocarpon thalli with maximum diameters, which also present processes of disintegration.

The ramparts present many of the characteristics described by Shakesby et al. (1999) for the pronival ridges formed by subnival push of mobile snow patches, particularly the arcuate plan of the frontal ramparts, the asymmetry of the cross-section profiles, the presence of embedded blocks in the proximal faces of the frontal accumulations, as well as the abraded edges and faces of the clasts of which they are composed.

The processes that have generated PR1, PR2 and PR3 ramparts are subnival glide and full-depth avalanches. Clearly, the conditions for their formation must have been met during heavy snowy periods or, alternatively, during periods of lower than present-day temperatures which allowed for greater permanence of the snow cover.

These characteristics appear to coincide with those which arose during the LIA in the north-west of the Iberian Peninsula and which have been recorded in detail as far as the decrease in average temperatures of between 2 and $2.5^{\circ} \mathrm{C}$ are concerned, via the study of the accumulation of $\mathrm{Hg}$ in the ombrotrophic peat bogs of the Xistral Mountains, located $100 \mathrm{~km}$ to the north-west of our study area (Martínez Cortizas et al., 1999a, 1999b). For the period 1500-1900 in the Northwest of the Iberian Peninsula, Saz Sánchez et al. (2004) estimated temperatures in general below those estimated for the Standard Reference Period from 1971 to 2000, which are considered as representative of the current climate. These authors estimate the average values at $0.5^{\circ} \mathrm{C}$ less than the period between 1971 and 2000 , with the difference being more intense $\left(0.8^{\circ} \mathrm{C}\right)$ in the three months of summer. This value is extremely interesting as far as our study is concerned, 
as it corresponds to the temperatures of the months in which the melting of the seasonal snow patch occurred.

The presence of over-accumulation due to the falling of blown snow cornices must have played a key role in all of the phases as this supposes an additional source of snow. In the current climate pattern significant snowfall usually occurs at the end of the winter or at the beginning of the spring, with a large amount of snow accumulating in a short period of time. The slow subnival gliding destabilises the snow cover and triggers full-depth avalanches, creating significant pressures on the substrate, leading to detachment of bedrock fragments and abrasion of rock surfaces. Finally, if the snow cover is deep enough, it can affect the pronival ramparts, modifying them and leaving more detailed evidence on their western section (Figure 3b), possibly due to the fact that more snow accumulates in this area. This factor depends on the net accumulation of snow and on whether it remains in place late in the ablation season. Factors to be taken into account include snowfall, snow blow and spring and summer temperatures. Therefore, the dynamics of the snow cover does not necessarily depend on climatic cooling processes of the type which arose in the LIA, although it can be influenced by the disturbance of atmospheric circulation patterns connected to the former (for example, an increase in cyclonic activity (Lamb, 1977), which lead, along with a fall in temperatures, to an increase in snow precipitation. Indeed, this can coincide with periods in which the temperature decreases in summer months (Saz Sánchez et al., 2004).

\section{Conclusions}

The lichenometrical dating of the different sectors of the pronival ramparts associated to the late-lying snow patch of Pico Cuiña indicate early snow-push activity coinciding, broadly speaking, with the beginning of the LIA in Europe (the second half of the 15 th century).

It can be speculated that the main action of the snow patch was to relocate a large amount of material that was previously located further upslope, thus revealing the significance of the rampart in terms of volume.

The next dated snow-push events correspond to the middle of the 18th century, a cold context. An event occurred later, originating a slight overlapping with pre-existing ramparts. The last dated snow-push event attributed to the LIA corresponds to the year 1887.

The most recent data appear to indicate that the factors controlling the dynamics of the snow cover are primarily snowfall intensity and, to a lesser extent, low temperatures being experienced late in the ablation season. However, the good fit between the dates obtained and the behaviour of the European climate indicate that these two factors have similar significance.

\section{Acknowledgements}

The authors would like to thank Uxío Valcárcel, J. Martínez Piñeiro, and R. Blanco Chao for their collaboration in this research. This work was funded through 
the support of Consolidación e Estructuración 2017 GRC GI-1667-RODA, ED431C 2017/26. Xunta de Galicia, Spain.

\section{References}

André, M.F. 1993. Les versants du Spitzberg: approche géographique des paysages polaires. Université de Nancy, Nancy, 361 pp.

Beschel, R. E. 1950. Flechten ais Altersmasstab rezenter Morranen. Zeitschrift für Gletscherkunde und Glazialgeologie 1, 152-161.

Carrera Gómez, P., Valcárcel, M. 2010. La acción geomorfológica del manto nivoso estacional en la Sierra de Ancares: vertiente nororiental del Pico Cuiña (León). Cuadernos de Investigación Geográfica 36 (2), 85-98. http://doi.org/10.18172/cig.1239.

Carrera Gómez, P., Valcárcel, M. 2011a. Detección de movimiento en la base del manto nivoso estacional en un sector del Pico Cuiña, Sierra de Ancares (León), Noroeste de la Península Ibérica. In: M. Valcárcel, P. Carrera Gómez (Eds.), Criosferas, suelos congelados y cambio climático. Universidade de Santiago de Compostela, pp. 37-40.

Carrera Gómez, P., Valcárcel, M. 2011b. La cubierta nival y su acción geomorfológica en el Pico Cuiña, Sierra de Ancares (NO de la Península Ibérica). In: M. Valcárcel, P. Carrera Gómez (Eds.), Criosferas, suelos congelados y cambio climático. Universidade de Santiago de Compostela, pp. 169-203.

Carrera Gómez, P., Valcárcel, M., Blanco Chao, R. 2010. Determinación de la duración del manto nivoso estacional en un sector del circo del Cuiña, Sierra de Ancares, NO de la Península Ibérica. In: X. Úbeda, D. Vericat, R. Batalla (Eds.), Avances de la Geomorfología en España 2008-2010. XI Reunión Nacional de Geomorfología. Sociedad Española de Geomorfología, Solsona, pp. 431-434.

Carrera Gómez, P., Valcárcel, M., Pérez Alberti, A. 2006. Ejemplos de formas erosivas de origen nival en las vertientes del Alto Ancares, Noroeste de la provincia de León. In: A. Pérez Alberti, J. López Bedoya (Eds.), Geomorfología y territorio. Actas de la IX Reunión Nacional de Geomorfología. Universidade de Santiago de Compostela, pp. 59-65.

Chueca, J. 1991. El sistema de protalus ramparts de la Coma de San Adrián (Macizo del Turbón, Huesca): caracterización cronológica mediante la utilización de técnicas liquenométricas. Actas del XIV Encuentro de Jóvenes Geógrafos, Zaragoza, pp. 114-128.

Chueca Cia, J., Julián Andrés, A. 1992. Establecimiento de una curva de crecimiento para el subgénero Rhizocarpon en el valle de Benasque (Pirineo Central Aragonés): aspectos metodológicos y resultados. In: F. López Bermúdez, C. Conesa, M.A. Romero (Eds.), Estudios de Geomorfología en España. Sociedad Española de Geomorfología, Murcia, pp. 729-739.

Chueca Cia, J., Julián Andrés, A. 1995. Datación de depósitos de derrubios gravitatorios a partir de técnicas liquenométricas (Alta Ribagorza, Pirineo oriental oscense). Lucas Mallada. Revista de Ciencias 7, 115-145. https://dialnet.unirioja.es/descarga/articulo/1090524.pdf.

Clarke, J., McClung, D. 1999. Full-depth avalanche occurrences caused by snow gliding, Coquihalla, British Columbia, Canada. Journal of Glaciology 45, 539-546. https://doi. org/10.3189/S0022143000001404.

Clauzade G., Roux, C. 1985. Likenoj de Okcidenta Europo. Ilustrita Determinlibro Bulletin de la Société Botanique du Centre-Ouest 7, 1-893.

Clauzade G., Roux, C. 1987. Likenoj de Okcidenta Europo. Suplelmento $2^{\circ}$. Bulletin de la Société Botanique du Centre-Ouest 18, 177-214.

Clauzade G., Roux, C. 1989. Likenoj de Okcidenta Europo. Suplelmento $3^{\circ}$. Bulletin de la Société Linnéenne de la Provence 40, 73-110. 
Feuerer, T. 1978. Zur Kenntnis der Flechtengattung Rhizocarpon in Bayern. Ber. Bayer. Bot. Ges. 49, 59-135. http://www.bbgev.de/berichte/049_1978/rhizocarpon.pdf.

Gordon, J.M., Sharp, M. 1983. Lichenometry in dating recent glacial landform and deposits, Southeast Iceland. Boreas 12 (3), 191-200. http://doi.org/10.1111/j.1502-3885.1983.tb00312.x.

Grove, J.M. 1988. The Little Ice Age. Methuen, London, 498 pp.

Iglesias, E., Iglesias, L. 1927. Impresiones de la excursión científica a la Sierra de los Ancares. Invernadero y Quija en el mes de Julio de 1927. Archivos do Seminario de Estudos Galegos II, 139-150.

Innes, J.L. 1982. Lichenometric use of an aggregated Rhizocarpon species. Boreas 11 (1), 53-57. http://doi.org/10.1111/j.1502-3885.1982.tb00520.x.

Lamb, H.H. 1977. Climate. Present, past and future. Volume 2. Climatic history and the future. Methuen, London, 613 pp.

Martínez Cortizas, A., Castillo Rodríguez, F., Blanco Chao, R. 1999a. Precipitación. In: A. Martínez Cortizas, A. Pérez Alberti (Eds.), Atlas climático de Galicia. Xunta de Galicia, Consellería de Medio Ambiente, Santiago de Compostela, pp. 75-91.

Martínez Cortizas, A., Castillo Rodríguez, F., Blanco Chao, R. 1999b. Temperatura. In: A. Martínez Cortizas, A. Pérez Alberti (Eds.), Atlas climático de Galicia. Xunta de Galicia, Consellería de Medio Ambiente, Santiago de Compostela, pp. 93-105.

Martínez Piñeiro, J., Valcárcel Díaz, M., Martínez Cortizas, A., Pérez Alberti,A. 1998. Elaboración de una curva de crecimiento (subgénero Rhizocarpon ) para la Serra dos Ancares (NW Península Ibérica). In, A. Gómez Ortiz, F. Salvador Franch (Eds.), Investigaciones recientes de la geomorfología española. Universitat de Barcelona, pp. 735-740.

Mateo García, M. 1998. El método de datación liquenométrico. La curva de crecimiento del Rhizocarpon geographicum establecida para el valle del Madriu (Andorra). In: A. Gómez Ortiz, F. Salvador Franch, L. Schulte, A. García Navarro (Eds.), Procesos biofísicos actuales en medios fríos. Universitat de Barcelona, pp. 327-346.

Mateo García, M., Gómez Ortiz, A. 1998. El glaciarismo histórico. La Pequeña Edad del Hielo en el valle del Madriu (Andorra). In: A. Gómez Ortiz, F. Salvador Franch (Eds.), Investigaciones recientes de la geomorfología española. Universitat de Barcelona, pp. 397-406.

Mathews, W.H., Mackay, J.R. 1963. Snowcreep studies, Mount Seymour, B.C.: preliminary field investigations. Geographical Bulletin 20, 58-75.

Mathews, W.H., Mackay, J.R. 1975. Snow creep: its engineering problems and some techniques and results of its investigation. Canadian Geotechnical Journal 12 (2), 187-198. https://doi. org/10.1139/t75-023

McClung, D. M., Walker, S., Golley, W. 1994. Characteristics of snow gliding on rock. Annals of Glaciology 19, 97-103. https://www.igsoc.org:8080/annals/19/igs_annals_vol19_year1994_ pg97-103.html.

Instituto Geográfico Nacional. (2014). Ortofotos PNOA.

Penas Merino, A., García González, M.E., Herrero Cembranos, L, Puente García, E. 1995. Pisos bioclimáticos: Ombrotipos. In: A. García Cortés, E. Gallego Valcarce, D. Barettino Fraile (Eds.), Atlas del medio natural de la provincia de León. Instituto Tecnológico Geominero de España, Madrid, pp. 23-24.

Pérez Estaun, A. 1978. Estratigrafía y estructura de la rama S. de la Zona AsturoccidentalLeonesa. Instituto Geológico y Minero de España, Madrid, 149 pp.

Pérez López, R., Martín González, F., Martínez Díaz, J.J., Rodríguez-Pascua, M.A. 2012. Datación mediante liquenometría de los desprendimientos rocosos asociados a la sismicidad histórica en Lorca (Murcia, SE de España). Boletín Geológico y Minero 123, 473-485. http://www. igme.es/Boletin/2012/123_4/8_ARTICULO\%205.pdf. 
Poelt, J. 1988. Rhizocarpon Ram. em. Th. Fr. subgen. Rhizocarpon in Europe. Arctic and Alpine. Research 20 (3), 292-298. http://doi.org/10.2307/1551261

Purvis, O.W, Coppins, B.J, Hawksworth DL, James P.W, Moor, D.M. 1992. The Lichen Flora of Great Britain and Ireland. London.Natural History Museum \& British Lichen Society, London, $710 \mathrm{pp}$.

Redondo Vega, J.M., Gómez Villar, A., González Gutiérrez, R.B., Santos González, J. 2010. Los glaciares rocosos de la Cordillera Cantábrica. Secretariado de Publicaciones, Universidad de León, 171 pp.

Rodríguez Guitián, M., Guitián Rivera, J. 1993. El piso subalpino en la Serra dos Ancares: Condicionantes geomorfológicos y climáticos de la distribución de las comunidades vegetales. In: A. Pérez Alberti, L. Guitián Rivera, P. Ramil Rego (Eds.). La evolución del paisaje en las montañas del entorno de los Caminos Jacobeos. Xunta de Galicia, Santiago de Compostela, pp. 165-181.

Runemark, H. 1956. Studies in Rhizocarpon I: Taxonomy of the yellow species in Europe. Opera Botanica 2, 1-152.

Santos González, J., Redondo Vega, J. M., Gómez Villar, A., González Gutiérrez, R.B. 2010. Dinámica actual de los nichos de nivación del Alto Sil (Cordillera Cantábrica). Cuadernos de Investigación Geográfica 36 (1), 87-106. http://doi.org/10.18172/cig.1229.

Saz Sánchez, M.Á., Creus Novau, J., Cuadrat Prats, J.M. 2004. La Pequeña Edad del Hielo en Galicia: reconstrucción de las temperaturas de Labacolla entre los siglos XVI y XIX. Xeográfica. Revista de Geografía, Territorio e Medio Ambiente 4, 142-161.

Schroeder-Land, H. 1983. Establishing lichen growth curves by repeated size (diameter) measurements of lichen individua in a test area -a mathematical approach-. In: H. SchroederLand (Ed.), Late- and Postglacial Oscillations of Glaciers. A. A. Balkema, Rotterdam, pp. 393-409.

Serrano, E. 1991. Geomorfología glaciar de las montañas y valles de Panticosa y de la Ribera de Biescas (Pirineo aragonés). Doctoral dissertation, Universidad Autónoma de Madrid, 952 pp.

Shakesby, R.A., Matthews, J.A., Berrisford, M.S., McEwen, L.J. 1999. Snow-push processes in pronival (protalus) rampart formation: geomorphological evidence from Smorbotn, Romsdalsalpane, Southern Norway. Geografiska Annaler, Series A, Physican Geography 81 (1), 31-45. http://doi.org/10.1111/j.0435-3676.1999.00047.x.

Thomson, J.W. 1967. Notes on Rhizocarpon in the arctic. Nova Hedwigia 14, 421-481.

Valcárcel, M. 1998. Evolución geomorfológica y dinámica de las vertientes en el NE de Galicia. Importancia de los procesos de origen frío en un sector de las montañas lucenses. Doctoral dissertation. Universidade de Santiago de Compostela, 496 pp.

Valcárcel, M., Carrera Gómez, P., Pérez Alberti, A. 2005. Nival bedrock erosion a seasonal snow patch site from the Cuiña cirque. Ancares Sierra, north-western Spain. In: S. Etienne (Ed.), Shifting lands, new insights into periglacial geomorphology. Séteun, Clermont-Ferrand, pp. 94-95.

Valcárcel, M., Pérez Alberti, A. 2002. La glaciación finipleistocena en el sector noroccidental de las montañas leonesas: la Sierra de Ancares. In: J.M. Redondo Vega, A. Gómez Villar, R.B. González Gutiérrez (Eds.), El modelado de origen glaciar en las montañas leonesas. Universidad de León, pp. 67-102.

Werner, A. 1990. Lichen growth rate for the northwest coast of Spitsbergen, Svalbard. Artic and Alpine Research 22, 129-140. http://doi.org/10.2307/1551298. 